\title{
Hak atas Pemulihan Korban Pelanggaran Berat HAM di Indonesia dan Kaitannya dengan Prinsip Tanggung Jawab Negara dalam Hukum Internasional
}

\author{
Andrey Sujatmoko*
}

\begin{abstract}
Abstrak
Salah satu karakteristik negara hukum mensyaratkan adanya perlindungan hak asasi manusia dan UUD 1945 menyatakan hal itu secara eksplisit. Oleh karena itu, pelanggaran berat HAM akan bertentangan dengan UUD 1945. Pelanggaran berat HAM seringkali meninggalkan masalah kemanusiaan, antara lain berupa korban dalam skala besar yang lazimnya baru dapat teridentifikasi setelah pelanggaran berakhir dan hal itu pun terjadi di Indonesia. Hingga saat ini Indonesia masih abai terhadap para korban, meskipun sesungguhnya mereka memiliki hak atas pemulihan yang dijamin hukum internasional. Berdasarkan prinsip tanggung jawab negara, Indonesia secara hukum wajib melakukan pemulihan terhadap para korban. Langkah pemulihan dapat diawali dengan membentuk Komisi Kebenaran dan Rekonsiliasi. Melalui kewenangannya, KKR dapat melakukan identifikasi dan investigasi para korban, lalu mempublikasikan hasil serta memberikan rekomendasi kepada pemerintah terkait model pemulihan berupa kompensasi, restitusi, dan rehabilitasi bagi para korban. Pemberian sejumlah uang, pengembalian hak, kedudukan, pekerjaan dan pelayanan kesehatan gratis adalah beberapa langkah konkretnya. Di samping itu, negara harus melakukan proses hukum terhadap para pelaku utama yang terkait.
\end{abstract}

Kata Kunci: hak atas pemulihan, hukum internasional, korban, pelanggaran berat HAM, tanggung jawab negara.

\section{The Right to Reparation of Gross Violations of Human Rights Victims in Indonesia and Its Relation with the Principle of State Responsibility in International Law}

\begin{abstract}
The existing protection of human rights is one of the characteristic of rule of law and it is explicitly stated in the Indonesian Constitution 1945. Accordingly, gross violations of human rights will be incompatible with the said Constitution. Gross violations of human rights have frequently left humanitarian problems behind such as victims in a large scale which commonly could only be identified when the violation has ended, such problem has also occurred in Indonesia. Until today, those victims have been ignored, although they have the right to reparation as guaranteed by international law. Based on the principle of state responsibility, Indonesia has legal obligation to conduct reparation to the victims
\end{abstract}

PADJADJARAN Jurnal IImu Hukum Volume 3 Nomor 2 Tahun 2016 [ISSN 2460-1543] [e-ISSN 2442-9325]

* Dosen Fakultas Hukum Universitas Trisakti, Jl. Kyai Tapa No. 1 Kampus A Grogol, Jakarta 11440, sujatmoko_a@yahoo.com, S.H., M.H. (Universitas Padjadjaran). 
concerned. The measure of reparation can be started by establishing the Truth and Reconciliation Commission. Through its competence, TRC will be able to conduct identification and investigation for the victims, to publish the result, and to address recommendation to the government regarding the reparation models, such as compensation, restitution, and rehabilitation to the victims. Granting sum of money; reestablishing right, status, employment and free health service are some practical measures of reparation. Furthermore, the government should also conduct judicial process to the main perpetrators concerned.

Keywords: the right to reparation, international law, victim, gross violations of human rights, state responsibility

\section{A. Pendahuluan}

Berbagai kasus pelanggaran berat hak asasi manusia (HAM) masa lalu seringkali meninggalkan banyak persoalan, terutama bagi korban. Hal itu terjadi karena korban biasanya berposisi lemah saat berhadapan dengan negara sebagai pelaku dan faktanya persoalan itu pun terjadi di Indonesia. Pandangan bawa para korban pelanggaran berat HAM berposisi lemah dan tidak diuntungkan dikatakan dengan tepat oleh seorang mantan Direktur Jenderal United Nations Educational, Scientific, and Cultural Organization (UNESCO) pada sebuah publikasi yang menandai perayaan ke-20 tahun Deklarasi Universal HAM (Universal Declaration of Human Rights). ${ }^{1}$

Impunitas terhadap para pelaku pelanggaran HAM masih dipraktikkan di banyak negara, terlebih menyangkut pelanggaran berat HAM (gross violations of human rights). Secara historis, hal tersebut terjadi pula di Indonesia yang ditandai oleh berbagai kasus pelanggaran HAM masa lalu, misalnya semasa rezim Orde Baru yang hingga kini masih belum terselesaikan. Di negeri ini, masih terdapat sejumlah kasus pelanggaran HAM yang tetap menimbulkan polemik berkepanjangan. Sebut saja pembantaian sesama anak bangsa yang terjadi sebelum dan sesudah pecahnya peristiwa Gerakan 30 September 1965 (G30S) dengan jumlah korban sekitar 75 ribu-1,5 juta orang, penembakan misterius atau Petrus 1982-1985 dengan jumlah korban sekitar 1.678 orang, kasus di Timor Timur pasca Referendum 1999 dengan korban 97 orang, juga kasus-kasus di Aceh pra Daerah Operasi Militer (DOM) 1976-1989 dengan korban ribuan orang. ${ }^{2}$

\footnotetext{
1 Renẻ Maheu, "Preface to Birthright of Man, an anthology of texts or human rights prepared under the direction of Jeanne Hersch", UNESCO, 1968, dalam Theo van Boven, "Victims' Rights to a Remedy and Reparation: The New United Nations Principles and Guidelines", dalam buku Reparations for Victims of Genocide, War Crimes and Crimes against Humanity, yang disusun oleh Ferstman (et.al.) (eds), Netherlands: Koninklijke Brill NV, 2009, hlm. 19-20, http://www.corteidh.or.cr/tablas/r26214.pdf, diunduh 29 Maret 2015.

2 Komisi Nasional Hak Asasi Manusia (Komnas HAM), "Penantian Panjang Korban Pelanggaran HAM", http://www.komnasham.go.id/pemantauan-dan-penyelidikan-profil/penantian-panjang-korbanpelanggaran-ham, diunduh 17 April 2016.
} 
Selain itu, masih ada pula Kasus Tanjung Priok 1984 dengan korban 74 orang, kasus-kasus di Papua 1966-2007 dengan korban ribuan orang, kasus Dukun Santet Banyuwangi 1998 dengan korban puluhan orang, kasus Marsinah 1995, kasus hilangnya Wiji Thukul, kasus Bulukumba 2003 dengan 2 korban tewas dan puluhan luka-luka, Talangsari Lampung pada tahun 1989, dengan korban 803 orang, kasus 27 Juli 1996 dengan jumlah korban 1.317 orang, Penembakan Mahasiswa Trisakti 1998 dengan korban 31 orang, Kerusuhan Mei 1998 dengan jumlah korban 1.308 orang, kasus Semanggi I 1998 dengan korban 473 orang, Semanggi II 1999 dengan korban 231 orang, serta Penculikan Aktivis 1998 dengan korban 23 orang. ${ }^{3}$

Kantor Komisi Tinggi HAM Perserikatan Bangsa-Bangsa (Office of the United Nations High Commissioner for Human Rights-OHCHR) menyatakan bahwa ketidakhadiran atau kolapsnya hukum di suatu negara dapat menimbulkan konflik kekerasan yang mengarah kepada pelanggaran berat HAM. Kemudian dikatakan pula bahwa impunitas seringkali merupakan penghalang bagi penegakan hukum dan menyebabkan tidak dihormatinya HAM, karena para pelanggar HAM bebas dari pertanggungjawaban. ${ }^{4}$

Kata 'impunity' yang ada dalam bahasa Inggris ternyata tidak ditemukan padanannya dalam bahasa Indonesia resmi, paling tidak menurut Kamus Besar Bahasa Indonesia yang diterbitkan oleh Balai Pustaka. Beberapa kalangan, terutama advokat HAM, menggunakan kata impunitas sebagai padanannya dalam bahasa Indonesia. Kata itu sendiri juga tidak lazim digunakan oleh publik secara luas dalam bahasa pergaulan sehari-hari. Kata 'impunity' yang berasal bahasa Latin 'impunitas' berasal dari akar kata 'impune' yang artinya 'tanpa hukuman'.

Seiring dengan kemajuan sistem hukum dan tata negara, definisi 'impunity' dalam kerangka hukum internasional adalah:

"Ketidakmungkinan-de jure atau de facto-untuk membawa pelaku pelanggaran HAM mempertanggungjawabkan perbuatannya baik dalam proses peradilan kriminal, sipil, administratif, atau disipliner karena mereka tidak dapat dijadikan objek pemeriksaan yang memungkinkan dapat terciptanya penuntutan, penahanan, pengadilan, dan apabila dianggap bersalah, penghukuman dengan hukuman yang sesuai, dan untuk melakukan reparasi kepada korbankorban mereka." ${ }^{\prime 6}$

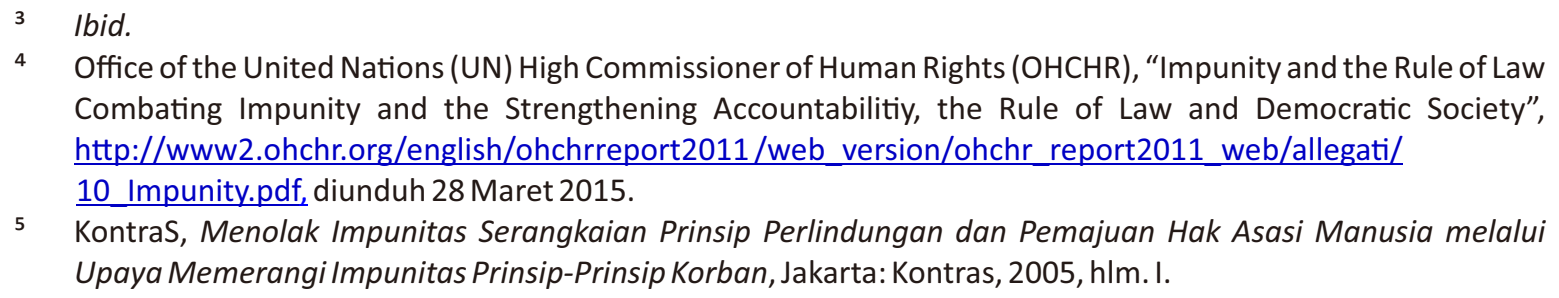
Combating Impunity and the Strengthening Accountabilitiy, the Rule of Law and Democratic Society", http://www2.ohchr.org/english/ohchrreport2011/web_version/ohchr_report2011_web/allegati/ 10 Impunity.pdf, diunduh 28 Maret 2015.

5 KontraS, Menolak Impunitas Serangkaian Prinsip Perlindungan dan Pemajuan Hak Asasi Manusia melalui Upaya Memerangi Impunitas Prinsip-Prinsip Korban, Jakarta: Kontras, 2005, hlm. I.

$6 \quad$ Ibid. 
Gambaran masih terjadinya impunitas dapat dirujuk pada sejumlah kasus pelanggaran berat HAM masa lalu yang belum terselesaikan hingga kini, antara lain: pembunuhan secara massal terhadap orang-orang yang diduga sebagai anggota /simpatisan Partai Komunis Indonesia (PKI), termasuk mengasingkan mereka ke pulau Buru; pembunuhan dengan cara ditembak (dikenal dengan istilah 'petrus'/'penembak misterius') terhadap orang-orang yang diduga sebagai pelaku kriminal; penculikan para aktivis HAM tahun 1997; pelanggaran HAM dalam konflik bersenjata di Aceh; peristiwa 12 Mei 1998 berupa kerusuhan/huru-hara yang disertai dengan perusakan atas harta benda, pembakaran, pembunuhan dan perkosaan; serta pelanggaran HAM di Timor Timur dan kasus Tanjung Priok. ${ }^{7}$

Selama 16 tahun pasca reformasi (terhitung hingga tahun 2014-Pen.), berbagai inisiatif telah dilakukan untuk menggali jalan penyelesaian atas tuntutan keadilan dari para korban dan masyarakat sipil. Keseluruhan langkah itu tertuang dalam berbagai kebijakan yang dilahirkan pemerintah dalam berbagai bentuknya. Namun keseluruhan langkah kebijakan tersebut belum menghasilkan langkah berarti, baik karena minim dukungan politik maupun karena bersifat parsial dan kurang komprehensif, sehingga tidak menghasilkan fondasi bagi langkah penyelesaian yang berkelanjutan dan komprehensif. ${ }^{8}$

Tidak satupun hak-hak korban - baik hak untuk mengetahui, hak atas keadilan, dan hak atas pemulihan/reparasi-dipenuhi negara. Masalah ini bisa kita lihat pada hasil Pengadilan HAM ad hoc kasus Timor Timur dan Tanjung Priok, juga dalam beberapa kasus semasa Orde Baru yang sama sekali masih diabaikan seperti kasus pembantaian massal 1965, penahanan semena-mena di luar proses hukum bagi korban kasus 1965 di Pulau Buru, kasus-kasus yang terkait dengan Timor Timur selama dikuasai oleh Orde Baru, kasus-kasus akibat operasi militer di Aceh dan Papua dan masih banyak lagi. ${ }^{9}$

Presiden Joko Widodo menegaskan bahwa pemerintah tetap konsekuen menyelesaikan 6 (enam) kasus prioritas pelanggaran HAM berat agar bangsa Indonesia terbebas dari beban masa lalu. Namun presiden juga turut mengingatkan agar semua pemangku kepentingan lebih bijak mengomentari setiap tahap penyelesaian yang tengah dijalankan. Pemerintah sendiri tidak ingin penyelesaian dilakukan secara konfrontatif. ${ }^{10}$ Enam kasus prioritas yang dimaksud

7 Sesuai data Komnas HAM, ada 7 (tujuh) berkas pelanggaran HAM berat masa lalu. Berkas tersebut terkait dengan kasus peristiwa 1965-1966; Penembakan Misterius 1982-1985; Talang Sari di Lampung (1989); Penghilangan Orang Secara Paksa 1997-1998; Kerusuhan Mei 1998; Peristiwa Trisakti; Semanggi I, Semanggi II; serta peristiwa Wasior dan Wamena (2003). Vide Kompas, "Hak Asasi Manusia: Pemerintah Bertekad Tuntaskan Kasus Lama”, 22 April 2015, hlm. 4; dan The Jakarta Post, “Rights Abuse Task Force to be Set Up”, 22 April 2015, hlm. 1.

8 Komisi Nasional Hak Asasi Manusia Republik Indonesia (Komnas HAM RI), Ringkasan Eksekutif Laporan Penyelidikan Pelanggaran Hak Asasi Manusia Berat, Jakarta: Komnas HAM RI, 2014, hlm. iii.

9 KontraS, Op. cit., hlm. xi.

10 Kompas, "Pelanggaran HAM: Presiden: Penyelesaian Jangan Konfrontatif”, 21 April 2016, hlm. 5. 
presiden adalah kasus peristiwa 1965-1966; penembakan misterius 1982-1985; peristiwa Talangsari 1989 (Lampung); penghilangan orang secara paksa 1997-1998; Kerusuhan Mei 1998; serta peristiwa Trisakti, Semanggi I, dan Semanggi II..

Namun demikian, langkah konkret pemenuhan hak atas pemulihan para korban hingga kini baru sebatas wacana. Upaya yang telah dilakukan hanyalah koordinasi antarlembaga negara untuk membahas kasus-kasus pelanggaran berat masa lalu yang melibatkan Komisi Nasional HAM (Komnas HAM), Kejaksaan Agung, Tentara Nasional Indonesia (TNI), dan Kepolisian Republik Indonesia (Polri).

Hukum internasional mengatur bahwa negara harus bertanggung jawab atas setiap pelanggaran HAM yang terjadi di wilayahnya. Menurut prinsip tanggung jawab negara, pelanggaran berat HAM dapat dikategorikan sebagai tindakan salah secara internasional (internationally wrongful act). Tindakan tersebut diatur dalam Pasal 1 International Law Commission Draft on Responsibility of States for Internationally Wrongful Act 2001 (Draft ILC 2001) yang menyatakan bahwa setiap tindakan salah secara internasional suatu negara akan menimbulkan pertanggungjawaban internasional dari negara tersebut. ${ }^{12}$

Pasal 2 Draft ILC 2001 mengatur bahwa tindakan salah tersebut timbul ketika perbuatan yang berupa tindakan (action) atau kelalaian (omission) dapat dipertanggungjawabkan kepada negara menurut hukum internasional dan menimbulkan suatu pelanggaran atas suatu kewajiban internasional dari negara. ${ }^{13}$ Berdasarkan Pasal 31 ayat (1) Draft ILC 2001, negara yang harus bertanggung jawab dan berkewajiban untuk melakukan pemulihan secara penuh (full reparation) atas kerugian (injury) yang timbul yang disebabkan oleh tindakannya tersebut. ${ }^{14}$ Sedangkan menurut Bing Cheng, hukum tanggung jawab negara dapat diterapkan pada pelanggaran HAM, sebab pelanggaran HAM akan menimbulkan pelanggaran atas kewajiban internasional menyangkut HAM yang telah diakui secara internasional. ${ }^{15}$

Sementara itu berdasarkan prinsip tanggung jawab negara, negara harus melakukan pemulihan atas pelanggaran HAM yang terjadi. Kepada pelaku, negara wajib melakukan proses hukum terhadap mereka yang bertanggung jawab atas terjadinya pelanggaran HAM. Kepada korban, negara wajib memberikan kom-

$11 \quad$ lbid.

12 Teks asli Pasal 1 International Law Commission Draft on Responsibility of States for Internationally Wrongful Act (Draft ILC 2001): "Every international wrongful act of a State entails international responsibility of that State".

13 Teks asli Pasal 2 Draft ILC 2001: "There is an internationally wrongful act of a State when conduct consisting of an action or omission: (a) is attributable to the State under international law; and (b) constitutes a breach of an international obligation of the State".

14 Teks asli Pasal 31 ayat (1) Draft ILC 2001: "1. The responsible State is under an obligation to make full reparation for the injury caused by the internationally wrongful act".

15 Dinah Shelton, Remedies in International Human Rights Law, New York: Oxford University Press, 1999, hlm. 93, sebagaimana mengutip Bing Cheng, General Principles of Law as applied by International Courts and Tribunals 
pensasi, restitusi, rehabilitasi, dan jaminan tidak terulangnya peristiwa serupa. Hal semacam ini dapat ditemukan dalam beberapa dokumen, seperti: the United Nations Basic Principles and Guidelines on the Right to a Remedy and Reparation for Victims of Gross Violations of International Human Rights Law and Serious Violations of International Humanitarian Law (Basic Principles and Guidelines) dan the General Comment No. 3 of the UN Committee against Torture emphasises that 'the comprehensive reparative concept' comprises of restitution, compensation, rehabilitation, satisfaction and guarantees of non-repetition (Komentar Umum). ${ }^{16}$

Terkait pelanggaran HAM berupa tindakan penyiksaan, Komentar Umum No. 3 Komite menentang Penyiksaan Perserikatan Bangsa-Bangsa (PBB) menjelaskan istilah restitusi, kompensasi, dan rehabilitasi. Menurut Komentar Umum, yang dimaksud dengan restitusi adalah suatu bentuk upaya yang diciptakan untuk mengembalikan kembali kepada situasi (re-establish) seperti sebelum terjadinya penyiksaan. Kompensasi diartikan mengacu kepada pemberian uang yang diberikan kepada para korban penyiksaan atas kerugian yang dapat dinilai secara ekonomi yang ditimbulkan dari penyiksaan atau perlakuan yang menyakitkan. Rehabilitasi diartikan sebagai suatu bentuk upaya yang berupa penanganan yang bersifat medis dan psikologis dan pelayanan sosial bagi para korban penyiksaan. ${ }^{17}$

Berdasarkan uraian di atas dapat dikatakan bahwa di Indonesia masih terdapat sejumlah kasus pelanggaran berat HAM masa lalu yang belum diselesaikan oleh negara. Pembiaran atas kasus-kasus tersebut berarti negara melakukan impunitas yang dilarang oleh hukum HAM internasional. Dalam perspektif korban, negara pun masih abai dalam memenuhi hak atas pemulihan korban.

\section{B. Negara Hukum dan Tanggung Jawab Negara}

Literatur menyebutkan bahwa pemikiran mengenai negara hukum lahir di dunia Barat dimulai dari pemikiran Plato (Filsuf Yunani Kuno). Dalam bukunya yang berjudul The Republic, hukum di dalam pikiran Plato dikonsepsikan sebagai penjelmaan cara berpikir yang benar (the higher of reasoning). Oleh karena itu, menurut konsep Plato, penyelenggaraan negara yang baik haruslah didasarkan pada hukum atau nomoi. ${ }^{18}$

Mengacu kepada pendapat di atas, maka baik buruknya negara dapat dilihat dari ketaatannya pada hukum. Terkait dengan HAM, dapat diasumsikan bahwa

(1953), 170. Dengan kutipan aslinya sebagai berikut "Clearly, the law of state responsibility remains applicable to the violation by a state of internationally-recognized human rights, because such an act constitutes a breach of an international obligation."

16 Era Purnama Sari, "Reparation for Torture Victims in Theory and Practice", Article 2 of the International Covenant on Civil and Political Rights, Vol. 12, No. 3, 2013, hlm. 16.

17 Ibid.

18 I Dewa Gede Atmadja (et.al.), Teori Konstitusi dan Konsep Negara Hukum, Malang: SETARA Press, 2014, hlm. 122. 
kekuasaan negara yang sangat besar perlu dibatasi hukum untuk mencegah terjadinya penyalahgunaan kekuasaan (abuse of power) yang kemudian akan menimbulkan pelanggaran HAM.

Menurut Sudargo Gautama, paham negara hukum berasal dari ajaran kedaulatan hukum, ia memberikan pengertian hal itu sebagai negara di mana alat-alat negaranya tunduk pada aturan hukum. Soediman Kartohadiprodjo mendefinisikan negara hukum sebagai negara di mana nasib dan kemerdekaan orang-orang didalamnya dijamin sebaik-baiknya oleh hukum. ${ }^{19}$ Inti dari pengertian negara hukum dari kedua sarjana Indonesia yang cukup terkemuka tersebut tampaknya samasama menekankan tentang tunduknya penguasa terhadap hukum sebagai esensi negara hukum. ${ }^{20}$

Apabila dikaji dari latar belakang dan sistem hukum yang menopangnya, ada perbedaan antara konsep 'rechtsstaat' dengan konsep 'rule of law', walaupun pada dasarnya kedua konsep itu mengarahkan dirinya pada satu sasaran utama, yaitu pengakuan dan perlindungan terhadap HAM, tetapi keduanya tetap berjalan dengan sistem hukum sendiri. ${ }^{21}$ Teori-teori ini menegaskan bahwa di Indonesia eksistensi HAM diakui dan dilindungi sebagai konsekuensi logis bahwa Indonesia adalah negara hukum (rechtsstaat) yang dinyatakan dalam Pasal 1 ayat (3) UndangUndang Dasar 1945 (UUD 1945). Terlebih lagi, Sila ke-2 Pancasila sebagai landasan filosofis nilai-nilai dan prinsip-prinsip kemanusiaan merupakan pengakuan atas HAM di Indonesia.

Karena terdapat penghargaan atas HAM, maka Indonesia dapat disebut sebagai negara yang berdasarkan hukum. Rasionya bahwa dalam negara hukum harus ada elemen-elemen sebagai berikut: (1) asas pengakuan dan perlindungan terhadap HAM; (2) asas legalitas; (3) asas pembagian kekuasaan; (4) asas peradilan yang bebas dan tidak memihak; dan (5) asas kedaulatan rakyat. ${ }^{22}$ Konsekuensi dari asas pengakuan dan perlindungan HAM ini menimbulkan tanggung jawab negara.

Hakikat pelanggaran HAM adalah penyalahgunaan kekuasaan oleh organ negara, oleh karena itu hal ini akan menyangkut pertanggungjawaban negara. Terkait hal itu, teori tanggung jawab negara objektif/teori risiko (risk theory) menjadi relevan. Menurut Malcolm N. Shaw, ${ }^{23}$ teori tanggung jawab negara objektif didasarkan pada prinsip pertanggungjawaban objektif yang menyatakan

\footnotetext{
Bahder Johan Nasution, Negara Hukum dan HakAsasi Manusia, Bandung: CV. Mandar Maju, 2012, hlm. 1.

Ibid.

Ibid., hlm. 4.

22 Mardenis, "Kontemplasi dan Analisis terhadap Politik Hukum Penegakan HAM di Indonesia", Jurnal Rechtsvinding, Volume 2, Nomor 3, Desember 2013, hlm. 441, sebagaimana mengutip Lili Rasyidi dan Ira Tania Rasyidi, Pengantar Filsafat Hukum, Bandung: Mandar Maju, 2002, hlm. 53. Artikel dapat diakses di http://rechtsvinding.bphn.go.id/artikel/ART\%209\%20JURNAL\%20VOLUME\%202\%20NO\%203 PROTEKSI.pdf.

Malcolm N. Shaw, International Law, $6^{\text {th }}$ Edition, Cambrigde: Cambridge University Press, 2008, hlm. 783.
} 
bahwa timbul tanggung jawab (liability) negara manakala terdapat tindakan tidak sah yang menyebabkan kerugian dan dilakukan oleh organ negara.

Penyelesaian pelanggaran berat HAM di Indonesia memerlukan hukum sebagai sarana untuk mewujudkan pemenuhan hak atas pemulihan korban. Oleh karena itu, perlu digunakan pula teori hukum pembangunan. Menurut Mochtar Kusumaatmadja, ${ }^{24}$ konsepsi hukum sebagai sarana pembangunan adalah bahwa hukum dalam arti kaidah atau peraturan hukum memang bisa berfungsi sebagai alat (pengatur) atau sarana pembangunan dalam arti penyalur arah kegiatan manusia ke arah yang dikehendaki oleh pembangunan dan pembaruan. ${ }^{25}$ Lebih jauh lagi, Soetandyo Wignjosoebroto menyatakan bahwa berdasarkan pemikiran Mochtar Kusumaatmadja tentang hukum tersebut, maka ia tak hanya merekonseptualisasikan hukum dari perannya sebagai pengatur tertib kehidupan sosial (yang telah mapan) ke fungsinya sebagai perekayasa sosial (demi terwujudnya pembangunan nasional). ${ }^{26}$

Telah menjadi suatu prinsip dalam hukum internasional bahwa setiap pelanggaran atas suatu kewajiban internasional akan menimbulkan kewajiban bagi negara pelanggar untuk melakukan pemulihan. Pandangan tersebut dinyatakan dalam putusan Mahkamah Permanen Internasional (Permanent Court of International Justice-PCIJ) dalam kasus the Corzow Factory. ${ }^{27}$ Demikian pula halnya dalam masalah HAM.

Pelanggaran tehadap HAM akan menimbulkan kewajiban bagi negara pelanggar untuk melakukan pemulihan. Menurut Theo van Boven, pengakuan mengenai hal itu terjadi sejak Perang Dunia II yang tidak lagi menjadikan persoalan HAM sebagai masalah eksklusif yurisdiksi domestik suatu negara dan para korban pelanggaran berat HAM memiliki hak untuk mengajukan pemulihan di forum pengadilan nasional maupun internasional. ${ }^{28}$ Theodor Meron pun menyatakan bahwa pelanggaran terhadap norma-norma hukum HAM dan hukum humaniter, baik kebiasaan internasional maupun perjanjian internasional, akan menimbulkan pertanggungjawaban negara secara internasional. ${ }^{29}$

24 Perkembagan pemikiran lihat di "Khazanah: Mochtar Kusumaatmadja” yang disusun oleh Atip Latipulhayat, Padjadjaran Jurnal IImu Hukum, Vol. 1, No. 3, 2014, hlm. 626-642.

25 Otje Salman dan Eddy Damian (eds), Konsep-Konsep Hukum dalam Pembangunan Kumpulan Karya Tulis Prof. Dr. Mochtar Kusumaatmadja, S.H., LL.M, Bandung: Pusat Studi Wawasan Nusantara, Hukum dan Pembangunan bekerja sama dengan PT. Alumni, 2006, hIm. 88.

26 Soetandyo Wignjosoebroto, Mochtar Kusuma-Atmadja: Manusia yang Pernah Saya Kenal dan Pemikirannya (Sebuah Pengantar Ringkas) dalam buku Mochtar Kusuma-Atmadja dan Teori Hukum Pembangunan Eksistensi dan Implikasi, yang disusun oleh Shidarta (eds), Jakarta: Epistema Institute, 2012, hlm. xxi.

27 D. J. Harris, Cases and Materials on International Law, London: Sweet and Maxwell, 1998, hlm. 29, sebagaimana mengutip P.C.I.J. Rep., Ser. A. No. 17, (1928).

28 Theo van Boven, Op.cit., hlm. 21.

29 Theodor Meron, Human Rights and Humanitarian Law as Customary Law, Oxford: Oxford University Press, 1991, hlm. 136. 
Selaras dengan pendapat di atas, Victor Condẻ menyatakan pula bahwa pelanggaran HAM pada hakikatnya merupakan pelanggaran terhadap kewajiban untuk mentaati norma hukum HAM internasional. Atas pelanggaran yang terjadi tersebut akan menimbulkan remedi, baik di tingkat nasional maupun internasional. ${ }^{30}$ Lalu istilah pelanggaran berat HAM yang dikenal dan digunakan pada saat ini sebenarnya belum dirumuskan secara jelas, baik dalam resolusi, deklarasi, maupun perjanjian internasional mengenai HAM. Namun hal itu secara umum dapat diartikan sebagai pelanggaran secara sistematis terhadap norma-norma HAM tertentu yang bersifat lebih serius, seperti: apartheid, diskriminasi rasial, pembunuhan, perbudakan, genocide, hingga persekusi berdasarkan agama dalam skala besar yang dilakukan sebagai praktik yang bersifat resmi.

Pelanggaran berat menimbulkan kerugian yang tidak dapat diperbaiki oleh para korbannya. ${ }^{31}$ Namun menurut Dinah Shelton, hukum HAM internasional, khususnya yang dikembangkan dalam lingkup PBB, sesungguhnya telah mengakui adanya pelanggaran HAM yang berkategori berat dan sistematis sebagaimana yang diatur dalam Resolusi Dewan Ekonomi dan Sosial (Economic and Social Council/ECOSOC) No. 1503. Walaupun pelanggaran tersebut belum didefinisikan secara jelas. ${ }^{32}$

Praktik yang terjadi terkait penyelesaian pelanggaran berat HAM tersebut menunjukkan bahwa para pelakunya diadili melalui forum pengadilan nasional. Namun demikian, apabila suatu negara tidak mampu (unable) atau tidak mau (unwilling) untuk menyelesaikannya, maka dapat diselesaikan melalui forum pengadilan internasional, baik yang bersifat ad hoc-misalnya Mahkamah Kejahatan Internasional untuk Bekas Yugosalvia tahun $1993^{33}$ dan Mahkamah Kejahatan Internasional untuk Rwanda tahun $1994^{34}$-maupun yang bersifat permanen, seperti Mahkamah Kejahatan Internasional (International Criminal Court-ICC) tahun $1998 .^{35}$

30 H. Victor Condẻ, A Handbook of International Human Rights Terminology, Lincoln: University of Nebraska Press, 1999, hlm. 156.

Ibid., hlm. 52.

32 Dinah Shelton, Op. cit., hlm. 320.

33 International Criminal Tribunal for the Former Yugoslavia (ICTY) didirikan berdasarkan Resolusi Dewan Keamanan Perserikatan Bangsa-Bangsa (PBB) No. 827 tanggal 25 Mei 1993.

34 International Criminal Tribunal for Rwanda (ICTR) didirikan berdasarkan Resolusi Dewan Keamanan PBB No. 955 tanggal 8 November 1994.

35 International Criminal Court (ICC) didirikan berdasarkan Statuta Roma yang disahkan dalam Konferensi Diplomatik PBB tentang Pendirian Mahkamah Kejahatan Internasional (United Nations Diplomatic Conference on the Establishment of an International Criminal Court) yang diadakan di Roma-Italia, 17 Agustus 1998, dengan 120 negara setuju, 7 menentang dan 21 abstain. Statuta Roma mulai berlaku (entry into force) sejak 1 Juli 2002. 


\section{Hak atas Pemulihan dan Pemulihan Korban}

Istilah pemulihan sebenarnya memiliki dua konteks yang berbeda. Pertama, dalam konteks bersifat yuridis, khususnya konteks hukum internasional, istilah ini digunakan dalam arti luas yang mengacu kepada seluruh upaya yang mungkin dapat dilakukan untuk memulihkan (redress) berbagai jenis kerugian yang telah diderita oleh para korban sebagai suatu akibat dari kejahatan tertentu. Termasuk ke dalam pengertian ini adalah pemulihan menurut hukum internasional, yaitu: restitusi, kompensasi, rehabilitasi, kepuasan (satisfaction), dan jaminan tidak terulangnya perbuatan serupa. ${ }^{36}$ Kemudian dalam konteks kedua, istilah pemulihan seringkali digunakan dalam mendesain program-program (misalnya menggambarkan serangkaian upaya-upaya pemulihan yang sifatnya lebih terkoordinasi atau kurang terkoodinasi). Sebagai contoh, Jerman, Chili, dan Argentina dapat dikatakan telah membuat 'program-program pemulihan'. ${ }^{37}$

Menurut Fiona McKay, sejumlah mekanisme internasional telah tersedia untuk memberikan jalan bagi upaya pemulihan untuk para korban pelanggaran HAM yang tidak mendapatkan remedi yang efektif dalam sistem negaranya sendiri, tetapi sedikit dari mekanisme tersebut yang dapat memerintahkan (order) dan memaksakan (enforce) ganti rugi atas kerugian dan bentuk-bentuk lain dari pemulihan kepada para korban. Beberapa mekanisme yang dapat melakukannya, seperti Pengadilan HAM dalam sistem regional Eropa dan Antar-Amerika, hanya dapat menerima kasus-kasus terhadap negara-negara peserta (contracting states) pada sistem tersebut dan relatif sedikit kasus-kasus yang diselesaikan melalui sistem tersebut. Dengan demikian, ICC merupakan mahkamah kejahatan internasional pertama yang mengizinkan para korban untuk meminta pemulihan dari para pelaku secara perorangan. ${ }^{38}$

Hak atas pemulihan korban pelanggaran berat HAM, antara lain dimuat dalam usulan mengenai prinsip-prinsip dasar (basic principles) dan petunjuk-petunjuk (guidelines) yang dibuat oleh Pelapor Khusus (Special Rapporteur) yang kemudian menjadi Prinsip Umum I. Prinsip tersebut menyatakan bahwa menurut hukum internasional, pelanggaran HAM menimbulkan hak atas pemulihan bagi korbannya.

Perhatian khusus harus diberikan terhadap pelanggaran berat HAM dan kebebasan-kebebasan dasar, yang setidaknya termasuk berikut ini: genocide;

36 Pablo de Greiff, "Justice and Reparations", dalam buku The Handbook of Reparations, yang disusun oleh Pablo De Greiff (eds), New York: Oxford University Press, 2006, hlm. 452.

37 Ibid., hlm. 453.

38 Fiona McKay, "Civil Reparation in National Courts for Victims of Human Rights Abuse", dalam buku Justice for Crimes against Humanity yang disusun oleh Mark Lattimer dan Philippe Sands (eds), Portland-Oregon: Hart Publishing, 2003, hlm. 283-284. 
praktik-praktik yang menyerupai perbudakan; eksekusi secara cepat atau sewenang-wenang; penyiksaan atau perlakuan atau penghukuman yang kejam, tidak manusiawi atau merendahkan; penghilangan orang secara paksa; perpanjangan penahanan yang sewenang-wenang atau pemindahan populasi secara paksa; dan diskriminasi secara sistematis, khususnya yang didasarkan pada ras dan perbedaan gender. $^{39}$

Menurut M. Cherif Bassiouni, sebenarnya PBB telah mengesahkan 2 (dua) deklarasi mengenai hak-hak korban. Deklarasi pertama berfokus pada korban 'domestic crimes' di tahun 1985 dan deklarasi kedua berfokus pada korban 'international crimes', terutama pelanggaran berat HAM dan pelanggaran serius hukum humaniter internasional. ${ }^{40}$

Hak atas pemulihan juga diatur dalam Prinsip-Prinsip Dasar dan PedomanPedoman PBB tentang Hak atas Remedi dan Pemulihan Korban Pelanggaran Berat Hukum HAM Internasional dan Pelanggaran Serius Hukum Humaniter Internasional (Basic Principles and Guidelines). ${ }^{41}$ Menurut Basic Principles and Guidelines, korban pelanggaran berat hukum HAM internasional dan pelanggaran serius hukum humaniter memiliki ruang lingkup yang luas.

Korban tidak saja bersifat individual/perorangan, tetapi juga dapat bersifat kolektif/kelompok. Termasuk juga dalam kategori korban adalah keluarganya dan orang-orang yang tergantung pada korban, serta orang-orang yang menderita kerugian dalam membantu membebaskan korban atau mencegah korban dari tindakan penghukuman. Status korban juga tidak tergantung pada keberadaan pelaku, artinya tanpa memperhatikan apakah pelaku sudah teridentifikasi, tertangkap, didakwa atau dijatuhi hukuman atau belum dan tanpa memperhatikan ada tidaknya hubungan keluarga antara korban dan pelaku. ${ }^{42}$

Definisi korban (yang intinya sama dengan di atas) juga terdapat di dalam Butir ke-18 Deklarasi PBB mengenai Prinsip-prinsip Dasar Keadilan bagi Korban-korban Kejahatan dan Penyalahgunaan Kekuasaan (the UN Declaration of Basic Principles of Justice for Victims of Crime and Abuse of Power) yang menyatakan bahwa pengertian korban termasuk pula orang-orang, baik perorangan atau kelompok, yang menjadi korban akibat perbuatan atau kelalaian yang walaupun belum

39 Theo van Boven, Op.cit., hlm. 33.

40 M. Cherif Bassiouni, "International Recognition of Victims' Rights", Human Rights Law Review, 2006, hlm. 203279.

41 The United Nations Basic Principles and Guidelines on the Right to a Remedy and Reparation for Victims of Gross Violations of International Human Rights Law and Serious Violations of International Humanitarian Law, adopted and proclaimed by General Assembly resolution 60/147 at 67 $7^{\text {th }}$ plenary meeting 16 December 2005 (Basic Principles and Guidelines).

42 Vide Prinsip V Nomor 8 dan 9 Basic Principles and Guidelines. 
merupakan pelanggaran terhadap hukum pidana nasional yang berlaku, tetapi merupakan pelanggaran norma-norma HAM yang diakui secara internasional. ${ }^{43}$

Aturan mengenai hak atas pemulihan juga terdapat dalam berbagai instrumen hukum HAM internasional, yaitu: Pasal 8 Deklarasi Universal HAM; Pasal 2 Kovenan Internasional tentang Hak-hak Sipil dan Politik (International Covenant on Civil and Political Rights-ICCPR); Pasal 6 Kovenan Internasional tentang Hak-hak Ekonomi, Sosial dan Budaya (International Covenant on Economic, Social, and Cultural Rights-ICESCR); Pasal 14 Konvensi Menentang Penyiksaan (Convention Against Torture); dan Pasal 39 Konvensi tentang Hak-hak Anak (Convention on the Rights of the Child). ${ }^{44}$

Hukum nasional juga telah mengatur hak atas pemulihan korban pelanggaran berat HAM. Hal itu antara lain diatur dalam Undang-Undang Nomor 26 Tahun 2000 tentang Pengadilan HAM (UU Pengadilan HAM); Peraturan Pemerintah Nomor 3 Tahun 2002 tentang Kompensasi, Restitusi, dan Rehabilitasi terhadap Korban Pelanggaran HAM yang Berat (PP 3/2002); Undang-Undang Nomor 13 Tahun 2006 tentang Perlindungan Saksi dan Korban (UU PSK); serta Peraturan Pemerintah Nomor 44 Tahun 2008 tentang Pemberian Kompensasi, Restitusi, dan Bantuan kepada Saksi dan Korban (PP 44/2008).

Sebenarnya politik hukum Indonesia pun telah secara tegas menentukan bahwa penyelesaian pelanggaran HAM akan didasarkan pada mekanisme hukum, yaitu dengan membentuk Komisi Kebenaran dan Rekonsiliasi (KKR) Nasional sebagai lembaga ekstra-yudisial yang jumlah anggota dan kriterianya ditetapkan dengan undang-undang. Komisi ini bertugas untuk menegakkan kebenaran dengan mengungkapkan penyalahgunaan kekuasaan dan pelanggaran HAM masa lalu sesuai hukum dan perundang-undangan yang berlaku dan melaksanakan rekonsiliasi. Setelah pengungkapan kebenaran dapat dilakukan, maka pengakuan kesalahan, permintaan dan pemberian maaf, perdamaian, penegakan hukum, amnesti, rehabilitasi, atau alternatif lain yang bermanfaat dapat dilaksanakan dengan memperhatikan rasa keadilan masyarakat. ${ }^{45}$

Tidak seperti opsi kebijakan amnesti, pembentukan komisi kebenaran mengindikasikan bahwa pemerintah yang baru merasa cukup aman untuk mengambil suatu langkah tentatif terhadap pelanggaran HAM yang dilakukan oleh rezim sebelumnya dengan cara mengidentifikasi mereka yang bertanggung jawab dan mengakui para korban. ${ }^{46}$ Singkatnya, komisi yang bersifat resmi ini meng-

43 The United Nations Declaration of Basic Principles of Justice for Victims of Crime and Abuse of Power Resolution adopted by the General Assembly resolution 40/34 at 96 $6^{\text {th }}$ plenary meeting 29 November 1985.

44 Vide bagian Mukadimah Basic Principles and Guidelines.

45 Vide Bab V Kaidah Pelaksanaan No. 3 TAP MPR No. V/MPR/2000 tentang Pemantapan Kesatuan dan Persatuan Nasional.

46 Brian Walsh, "Resolving the Human Rights Violations of a Previous Regime," World Affairs, Winter 1996, 158, 3, 
investigasi tuduhan pelanggaran HAM. Tujuan komisi adalah untuk menyediakan publik suatu penjelasan yang akurat mengenai kebijakan-kebijakan dan praktikpraktik dari rezim sebelumnya. ${ }^{47}$

Adapun arah kebijakan untuk mengadakan rekonsiliasi dalam rangka memantapkan usaha persatuan dan kesatuan nasional dapat dilakukan antara lain dengan menegakkan supremasi hukum dan perundang-undangan secara konsisten dan bertanggung jawab serta menjamin HAM. Langkah ini harus didahului dengan memproses dan menyelesaikan kasus-kasus korupsi, kolusi, dan nepotisme, serta pelanggaran $\mathrm{HAM}^{48}$

Melihat politik hukum dan peraturan perundang-undangan yang ada, pemenuhan hak atas pemulihan korban pelanggaran berat HAM seharusnya dapat terealisasi. Terkait hal itu, upaya konkret dapat diawali dengan membentuk lembaga $\mathrm{KKR}^{49}$ berdasarkan undang-undang. KKR selanjutnya memiliki peran sentral untuk mewujudkan hak-hak korban secara nyata. Berdasarkan kewenangannya, KKR dapat merancang hal-hal penting, seperti: menentukan ruang lingkup kasus yang akan diinvestigasi; menginventarisasi serta mengidentifikasi korban dan pelaku; mendesain bentuk-bentuk pemulihan; serta menyusun laporan hasil investigasi dan rekomendasi untuk disampaikan kepada pemerintah.

Pembatasan terhadap ruang lingkup kasus yang akan diinvestigasi mutlak dilakukan, mengingat KKR memiliki keterbatasan baik dari segi sumber daya manusia, sumber dana, maupun masa kerja yang cenderung singkat. Oleh karena itu, laporan hasil investigasi dan rekomendasi dari Komnas HAM mengenai kasuskasus pelanggaran berat HAM masa lalu dapat digunakan oleh KKR sebagai acuan kasus mana yang diprioritaskan dan segera ditindaklanjuti sesuai mandat dan kewenangannya.

Kasus-kasus yang dimaksud tersebut antara lain adalah: peristiwa 1965-1966; penembakan misterius 1982-1985; peristiwa Talangsari di Lampung 1989; penghilangan orang secara paksa 1997-1998; kerusuhan Mei 1998; peristiwa Trisakti, Semanggi I, dan Semanggi II; serta peristiwa Wasior dan Wamena 2003.

hlm. 112, mengutip Jorge Correa, "Dealing with the Past Human Rights Violations: the Chilean Case after Dictatorship", Notre Dame Law Review, 67, 1992, hlm. 1457.

47 Ibid, mengutip Juan E. Mendez, "Position of Americas Watch, a Division of Human Rights Watch on the Rights of Victims of Gross Violations of Human Rights to Reparations and on Measures to Prevent Such Violations," Paper presented at Seminar on the Right to Restitution, Compensation, and Rehabilitation for Victims of Gross Violations of Human Rights and Fundamental Freedoms, edited by Theo van Boven, (et.al.), Netherlands: Netherlands Institute for Human Rights, 1992, hlm. 188.

48 Vide Arah Kebijakan No. 4 Lampiran Pemantapan Kesatuan dan Persatuan Nasional (Persandingan Bab II, III, IV) Identifikasi Masalah TAP MPR No. V/MPR/2000 tentang Pemantapan Kesatuan dan Persatuan Nasional.

49 Pada tahun 2006 Mahkamah Konstitusi membatalkan Undang-Undang Nomor 27 Tahun 2004 tentang Komisi Kebenaran dan Rekonsiliasi (UU KKR) karena sejumlah pasal didalamnya dinilai bertentangan dengan UndangUndang Dasar 1945 (UUD 1945). Lihat Kompas, "Rekonsiliasi Menjadi Prioritas Hormati Perbedaan Pendapat", 20 April 2016, hlm. 5. 
KKR dapat memanfaatkan laporan hasil investigasi Komnas HAM atas ketujuh kasus tersebut, sehingga dapat mengurangi beban kerja KKR. Selanjutnya, KKR tinggal mencari data tambahan jika memang masih belum tersedia di dalam laporan tersebut dan mengklasifikasikan data sesuai dengan format, tujuan, serta kebutuhan yang telah ditentukan sebelumnya.

Laporan Komnas HAM di atas dapat dikatakan cukup komprehensif, sistematis, dan memuat data maupun analisis yang sangat penting artinya bagi KKR. Laporan itu secara garis besar berisikan tentang: deskripsi fakta peristiwa; analisis hukum (unsur-unsur kejahatan, bentuk kejahatan yang terjadi, gambaran pelaku atau pihak yang dapat dimintai pertanggungjawaban dan korban); kesimpulan; dan rekomendasi. ${ }^{50}$

Inventarisasi dan identifikasi korban merupakan hal paling esensial yang perlu dilakukan oleh KKR, di samping terhadap pelaku atau pihak-pihak yang dianggap bertanggung jawab dalam kasus tertentu. Perlu ditegaskan, menurut Basic Principles and Guidelines, status korban tidak tergantung pada keberadaan pelaku. Artinya status tersebut ada tanpa memperhatikan apakah pelaku sudah teridentifikasi, tertangkap, didakwa atau dijatuhi hukuman atau belum, dan tanpa memperhatikan ada tidaknya hubungan keluarga antara korban dan pelaku. Dengan perkataan lain, status korban tidak tergantung pada putusan pengadilan terkait pelaku, sehingga KKR dapat segera menentukan dan memutuskan 'nasib' korban tanpa menunggu proses hukum terhadap pelakunya. Sebaliknya, hal itu sangat berbeda dengan aturan yang berlaku serta praktik yang terjadi saat ini. Status korban serta pemenuhan atas hak-haknya sangat tergantung pada putusan pengadilan terhadap pelakunya.

Baik UU Pengadilan HAM maupun PP 3/2002, praktik kedua peraturan perundang-undangan tersebut tidak bersifat operasional. Terbukti dari kasus pelanggaran berat HAM di Timor Timur yang disidangkan di pengadilan HAM ad hoc, tidak satu pun amar putusan hakim yang memberikan hak atas pemulihan kepada pihak korban seperti yang telah diatur dan dijamin oleh kedua aturan tersebut.

Hal di atas sejalan dengan laporan yang dibuat oleh Lembaga Studi dan Advokasi Masyarakat (ELSAM) mengenai pelanggaran berat HAM di Timor Timur. yaitu dinyatakan bahwa hak khusus untuk para korban ini adalah hak mengenai pemberian kompensasi, restitusi, dan rehabilitasi yang ternyata juga tidak kunjung diberikan sedangkan peristiwa kejahatan yang dilakukan oleh terdakwa telah terbukti dan terdakwa dinyatakan bersalah dan dijatuhi pidana. ${ }^{51}$ Laporan itu juga

Vide Komnas HAM RI, Ringkasan Eksekutif..., Loc.cit.

51 Supriyadi Widodo Eddyono (et.al.), Perlindungan Saksi dan Korban, Catatan atas Pengalaman Pengadilan HAM Ad Hoc Kasus Pelanggaran Berat di Timor Timur, Jakarta: ELSAM, 2005, hlm. 7. Pada bagian catatan kaki dari 
menjelaskan bahwa aturan undang-undang yang mengatur tentang kompensasi, restitusi, dan rehabilitasi serta diperkuat dengan PP 3/2002 sampai saat ini tidak dapat dilaksanakan, karena sangat berkaitan dengan prosedur ganti kerugian seperti yang diatur dalam Kitab Undang-Undang Hukum Acara Pidana (KUHAP). Tidak satu pun jaksa yang menangani pelanggaran berat HAM ini mengajukan tuntutan adanya kompensasi, restitusi, maupun rehabilitasi ke pengadilan. ${ }^{52}$

Berdasarkan realita di atas, maka perlu dilakukan amandemen terhadap sejumlah aturan hukum yang menghambat realisasi pemenuhan hak-hak korban atau membuat aturan baru mengenai realisasi tersebut dengan prosedur yang berdiri sendiri. Kemudian peran KKR dimasukan sebagai lembaga yang berwenang untuk menentukan persoalan ganti rugi dan menggantikan peran pengadilan.

Terkait hal di atas, KKR perlu mendesain mekanisme, sumber, bentuk, serta besaran ganti rugi yang akan diberikan kepada korban, tentunya dengan berkordinasi dengan lembaga negara seperti Kementerian Keuangan menyangkut kompensasi. Terkait restitusi, KKR perlu memastikan bahwa hak para korban yang dirampas oleh negara (misalnya tanah milik) harus dikembalikan. Demikian pula bagi para korban yang kehilangan pekerjaan (misalnya sebagai PNS), maka hak pensiunnya harus dibayar oleh negara terhitung sejak mereka diberhentikan secara sepihak. Menyangkut rehabilitasi, KKR secara nasional dapat mendesain program yang berorientasi kepada pelayanan kesehatan (medis maupun psikologis) secara cuma-cuma dan berkelanjutan kepada para korban.

Sinergi antara KKR dan Lembaga Perlindungan Saksi dan Korban (LPSK) tampaknya diperlukan, mengingat lembaga ini telah berperan dalam pemenuhan hak-hak korban pelanggaran berat HAM seperti yang diatur dalam UU PSK. Melalui kerja sama, KKR dapat menyelaraskan, meneruskan, dan memperluas program yang telah dilakukan LPSK terhadap korban. Hal itu misalnya berupa bantuan medis dan bantuan rehabilitasi psiko-sosial, sebagaimana diatur dalam Pasal 5 UU PSK.

Berdasarkan PP 44/2008, permohonan kompensasi, ${ }^{53}$ restitusi, ${ }^{54}$ dan bantuan ${ }^{55}$ berupa bantuan medis serta rehabilitasi psiko-sosial harus diajukan oleh pihak korban kepada LPSK. Setelah itu, LPSK akan mengajukan permohonan tersebut kepada pengadilan HAM yang terkait dengan kasus yang dialami oleh korban. Dalam kaitan ini, KKR perlu secara tegas meminta pemerintah (dalam hal

kutipan dijelaskan pula bahwa semua amar putusan bagi para terpidana pelanggaran berat HAM di Timor Timur tidak ada yang menyebutkan tentang pemberian kompensasi dan restitusi. Lihat putusan terhadap terdakwa Abilio Soares, Eurico Guterres, Letkol. Soejarwo, AKBP. Hulman Gultom, dan Brigjen. Noer Muis.

52 lbid

53 Vide Pasal 2 Peraturan Pemerintah Nomor 44 Tahun 2008 tentang Pemberian Kompensasi, Restitusi, dan Bantuan Kepada Saksi dan Korban (PP 44/2008).

54 Vide Pasal 20 PP 44/2008.

55 Vide Pasal 34 PP 44/2008 
ini presiden) agar segera membentuk pengadilan HAM ad hoc untuk kasus pelanggaran berat HAM masa lalu yang direkomendasikan oleh KKR dalam rangka pemenuhan hak-hak korban.

Terkait dengan Pasal 6 UU PSK, LPSK ternyata sudah berperan dalam upaya yang diistilahkan dengan 'bantuan' (di dalam aturan hukumnya tidak disebut dengan istilah 'pemulihan') terhadap sejumlah korban kasus pelanggaran berat HAM di berbagai tempat di Indonesia, seperti peristiwa 1965, peristiwa Tanjung Priok 1984, serta kerusuhan Mei 1998 (termasuk penghilangan paksa).

Berdasarkan data mengenai hal layanan, LPSK tercatat telah melayani korban pelanggaran berat HAM dengan rincian sebagai berikut: ${ }^{56}$

Tabel 1. Data Periode Januari-Minggu I Oktober 2014

\begin{tabular}{|l|c|c|}
\hline \multicolumn{1}{|c|}{ Wilayah } & Medis & Psikologis \\
\hline D.I. Yogyakarta & 51 & 43 \\
\hline Sumatera Barat & 133 & 13 \\
\hline Jawa Timur & 38 & 10 \\
\hline Jawa Tengah & 243 & 215 \\
\hline Bali & 1 & - \\
Banten & 3 & 2 \\
\hline DKI Jakarta & 7 & 5 \\
\hline Jawa Barat & 51 & 17 \\
\hline Sumatera Utara & 10 & - \\
\hline Sulawesi Tengah & 8 & - \\
\hline Total & 745 & 305 \\
\hline
\end{tabular}

LPSK telah menganggarkan biaya bantuan medis dan psiko-sosial ini sejak tahun 2010. Anggaran medis digunakan untuk biaya pengobatan bagi para korban pelanggaran HAM yang berat serta pengobatan bagi korban kejahatan lainnya yang mengalami penderitaan. Sementara untuk biaya psiko-sosial yang digunakan bukan untuk pembiayaan psiko-sosial yang seutuhnya, namun hanya digunakan untuk konseling psikologi bagi para saksi dan korban yang terganggu psikisnya karena tindak pidana yang dialaminya. ${ }^{57}$

Dalam kurun waktu sejak tahun 2010 sampai 2011 biaya ini hanya digunakan untuk pembiayaan medis dan psikologis bagi saksi dan korban kejahatan lainnya. Tetapi pada tahun 2012, para korban pelanggaran HAM yang berat telah mulai

56 Rully Novian dan Susilaningtias, "Analisis Terhadap Definisi Korban dalam Pelaksanaan Bantuan Medis dan Psikososial Lembaga Perlindungan Saksi dan Korban", https://www.academia.edu/19896787/analisa_

definisi_korban_khususnya_korban pelanggaran_ham yang_berat, diunduh 26September 2016, hlm. 15-16. 
menerima manfaat. Pada tahun 2012 para korban yang pertama kali menerima manfaat adalah para korban kasus Tanjung Priok, keluarga korban tahun 1998, dan keluarga korban penghilangan paksa. ${ }^{58}$

Untuk ketiga kasus ini LPSK membiayai pengobatan medis dan psikologis korban yang secara langsung mengalami penderitaan beserta keluarganya. Selanjutnya menjelang akhir tahun 2012, LPSK menerima banyak permohonan bantuan medis dan psikologis dari para korban pelanggaran HAM yang berat, peristiwa tahun 1965, karena sekitar akhir bulan Juli 2012 Komnas HAM menyatakan bahwa peristiwa 1965 merupakan pelanggaran HAM yang berat. Sejak saat itu para korban peristiwa 1965 mengajukan permohonan ke LPSK untuk mendapatkan bantuan medis dan psikologis. ${ }^{59}$

Supremasi hukum merupakan inti dari proses penyelesaian pelanggaran berat HAM, termasuk dalam konteks pertanggungjawaban pelakunya. Hal tersebut sejalan dengan politik hukum, hukum positif yang berlaku, maupun prinsip-prinsip tanggung jawab negara dalam hukum internasional. Oleh karena itu, proses tersebut merupakan condition sine qua non. Walaupun pengalaman di banyak negara (misalnya Argentina dan Chili) menunjukkan bahwa proses hukum terhadap pelaku tidaklah mudah. Namun demikian, hal tersebut bukan mustahil untuk dilakukan, karena Indonesia pernah melakukannya (pada kasus: Tanjung Priok, Timor Timur, dan Abepura).

Terkait hal di atas, KKR berdasarkan data yang dimiliknya dapat mengidentifikasi pelaku utama sebagai pihak yang dianggap paling bertanggung jawab, lalu merekomendasikannya untuk diproses secara hukum melalui pengadilan HAM ad hoc. Namun hal itu dipastikan tidak akan mudah untuk dilakukan, sehingga membutuhkan kemauan, keberanian, dan kemampuan dari segenap aparat penegak hukum. Tentunya hal itu juga sangat memerlukan dukungan politik dari semua pihak.

Oleh karena itu, jalur non-yudisial dengan konsep rekonsiliasi menjadi perlu dikedepankan. "Rekonsiliasi didasarkan pada kemauan untuk berdamai dengan masa lalu dan kesepakatan membangun masa depan bersama yang damai", ujar Agus, Koordinator Koalisi Keadilan dan Pengungkapan Kebenaran Kamala Chandrakirana pun turut mengatakan bahwa penyelesaian yudisial dan nonyudisial bagaikan dua sisi mata uang sehingga kedua cara itu harus menunaikan hak-hak korban dan memberi jaminan tidak berulangnya kejahatan tersebut. ${ }^{60}$

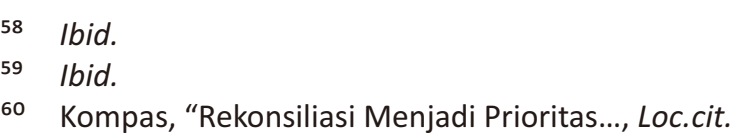




\section{Penutup}

Politik hukum, hukum nasional, maupun hukum internasional pada dasarnya telah mengatur dan menjamin hak atas pemulihan korban pelanggaran berat HAM. Di Indonesia, realisasi penyelesaian pelanggaran berat HAM harus dilakukan dalam rangka supremasi hukum. Menurut hukum nasional maupun hukum internasional, pelanggaran berat HAM menimbulkan tanggung jawab dari negara untuk melakukan pemulihan bagi para korbannya berupa kompensasi, restitusi, dan rehabilitasi.

Terkait hal di atas, KKR kedepannya merupakan lembaga yang memiliki peran yang sangat besar bagi penyelesaian pelanggaran berat HAM masa lalu di Indonesia, termasuk dalam pemenuhan hak-hak para korbannya. Walaupun saat tulisan ini dibuat KKR belum terbentuk, akan tetapi melihat politik hukum dan realitas sosial yang ada menginginkan agar KKR segera dibentuk dan dapat segera bekerja.

Secara garis besar, KKR berdasarkan kewenangannya dapat merancang hal-hal penting, seperti: menentukan ruang lingkup kasus yang akan diinvestigasi; menginventarisasi serta mengidentifikasi korban dan pelaku; serta menyusun laporan hasil investigasi dan rekomendasi untuk disampaikan kepada pemerintah (presiden). KKR perlu bekerja sama dengan lembaga-lembaga negara lainnya guna mempermudah dan memperlancar tugasnya, antara lain, Komnas HAM, LPSK, dan Kementerian Keuangan.

Upaya yang bersifat konseptual terkait status korban adalah dengan menggunakan Basic Principles and Guidelines sebagai acuan dalam menentukan status korban. Mengacu pada hal itu, status korban bersifat otonom sehingga tidak tergantung pada keberadaan pelaku. Status tersebut ada tanpa memperhatikan apakah pelaku sudah teridentifikasi, tertangkap, didakwa atau dijatuhi hukuman atau belum dan tanpa memperhatikan ada tidaknya hubungan keluarga antara korban dan pelaku. KKR juga perlu mengupayakan dilakukannya amandemen terhadap sejumlah aturan hukum yang menghambat realisasi pemenuhan hak-hak korban atau membuat aturan baru mengenai hal itu dengan prosedur yang berdiri sendiri. Kemudian, perlu dipastikan peran KKR sebagai lembaga berwenang untuk menentukan persoalan ganti rugi yang menggantikan peran pengadilan dalam rangka memangkas birokrasi.

\section{Daftar Pustaka}

\section{Buku}

Bahder Johan Nasution, Negara Hukum dan Hak Asasi Manusia, C.V. Mandar Maju, Bandung, 2012.

Condẻ, H. Victor, A Handbook of International Human Rights Terminology, University of Nebraska Press, Lincoln, 1999. 
de Greiff, Pablo (eds), The Handbook of Reparations, Oxford University Press, New York, 2006.

Ferstman (et.al.) (eds), Reparations for Victims of Genocide, War Crimes and Crimes against Humanity, Koninklijke Brill NV, Netherlands, 2009.

Harris, D. J., Cases and Materials on International Law, Sweet and Maxwell, London, 1998.

I Dewa Gede Atmadja (et.al.), Teori Konstitusi dan Konsep Negara Hukum, SETARA Press, Malang, 2014.

Kominis Nasional Hak Asasi Manusia Republik Indonesia, Ringkasan Eksekutif Laporan Penyelidikan Pelanggaran Hak Asasi Manusia Berat, Komnas HAM RI, Jakarta, 2014.

KontraS, Menolak Impunitas Serangkaian Prinsip Perlindungan dan Pemajuan Hak Asasi Manusia melalui Upaya Memerangi Impunitas Prinsip Prinsip Korban, KontraS, Jakarta, 2005.

Lattimer, Mark dan Philippe Sands (eds), Justice for Crimes against Humanity, Hart Publishing, Portland-Oregon, 2003.

Meron, Theodor, Human Rights and Humanitarian Law as Customary Law, Oxford University Press, Oxford, 1991.

Otje Salman dan Eddy Damian (eds), Konsep-Konsep Hukum dalam Pembangunan Kumpulan Karya Tulis Prof. Dr. Mochtar Kusumaatmadja, S.H., LL.M, Pusat Studi Wawasan Nusantara, Hukum dan Pembangunan bekerja sama dengan PT. Alumni, Bandung, 2006.

Shaw, Malcolm N., International Law, $6^{\text {th }}$ Edition, Cambridge University Press, Cambridge, 2008.

Shelton, Dinah, Remedies in International Human Rights Law, Oxford University Press, New York, 1999.

Shidarta (eds), Mochtar Kusuma-Atmadja dan Teori Hukum Pembangunan Eksistensi dan Implikasi, Epistema Institute, Jakarta, 2012.

Supriyadi Widodo Eddyono, (et.al.), Perlindungan Saksi dan Korban, Catatan atas Pengalaman Pengadilan HAM Ad Hoc Kasus Pelanggaran Berat di Timor Timur, ELSAM, Jakarta, 2005.

\section{Dokumen Lain}

Atip Latipulhayat, "Khazanah: Mochtar Kusumaatmadja", Padjadjaran Jurnal IImu Hukum, Vol. 1, No. 3, 2014.

Bassiouni, M. Cherif, "International Recognition of Victims' Rights", Human Rights Law Review, 2006, 6 (2), http://hrlr.oxfordjournals.org/content/6/2/203. abstract.

Era Purnama Sari, "Reparation for Torture victims in Theory and Practice", Article 2 of the International Covenant on Civil and Political Rights, Volume 12, Nomor 2 , 
Juni 2013.

Kompas, "Hak Asasi Manusia: Pemerintah Bertekad Tuntaskan Kasus Lama”, 22 April 2015.

2016.

, "Pelanggaran HAM: Presiden: Penyelesaian Jangan Konfrontatif", 21 April

_., "Rekonsiliasi Menjadi Prioritas Hormati Perbedaan Pendapat", 20 April 2016.

Mardenis, "Kontemplasi dan Analisis terhadap Politik Hukum Penegakan HAM di Indonesia", Jurnal Rechtsvinding, Volume 2, Nomor 3, Desember 2013, http://rechtsvinding.bphn.go.id/artikel/ART\%209\%20 JURNAL\%20

VOLUME\%202\%20NO\%203 PROTEKSI.pdf.

Office of the United Nations High Commissioner of Human Rights, "Impunity and the Rule of Law Combating Impunity and the Strengthening Accountabilitiy, the Rule of Law and Democratic Society", http://www2.ohchr.org/english/ ohchrreport2011/web version/ohchr report2011 web/allegati/10 Impun ity.pdf, diunduh 28 Maret 2015.

Rully Novian dan Susilaningtias, "Analisis Terhadap Definisi Korban dalam Pelaksanaan Bantuan Medis dan Psikososial Lembaga Perlindungan Saksi dan Korban", https://www.academia.edu/19896787/analisa definisi

korban_khususnya_korban pelanggaran_ham yang_berat, diunduh 26 September 2016.

The Jakarta Post, "Rights Abuse Task Force to be Set Up", diakses 22 April 2015.

Walsh, Brian, "Resolving the Human Rights Violations of a Previous Regime," World Affairs, Winter 1996, 158, 3.

\section{Dokumen Hukum}

Undang-Undang Dasar Tahun 1945.

TAP MPR No. V/MPR/2000 tentang Pemantapan Kesatuan dan Persatuan Nasional.

Peraturan Pemerintah Nomor 44 Tahun 2008 tentang Pemberian Kompensasi, Restitusi, dan Bantuan kepada Saksi dan Korban.

The United Nations Declaration of Basic Principles of Justice for Victims of Crime and

Abuse of Power Resolution adopted by the General Assembly resolution 40/34 at $96^{\text {th }}$ plenary meeting 29 November 1985.

The United Nations Basic Principles and Guidelines on the Right to a Remedy and Reparation for Victims of Gross Violations of International Human Rights Law and Serious Violations of International Humanitarian Law, adopted and proclaimed by General Assembly resolution 60/147 at $67^{\text {th }}$ plenary meeting 16 December 2005.

International Law Commission Draft on Responsibility of States for Internationally WrongfulAct 2001. 
Resolusi Dewan Keamanan PBB Nomor 827 tanggal 25 Mei 1993.

Resolusi Dewan Keamanan PBB Nomor 955 tanggal 8 November 1994. 